\title{
(Re)politicising the dead in post-Holocaust Poland: the afterlives of human remains at the Bełzec extermination camp ${ }^{1}$
}

\section{Zuzanna Dziuban}

At the official dedication of the Memorial to the Murdered Jews of Europe on 10 May 2005 in Berlin, Lea Rosh, a German journalist who launched and led the long-lasting campaign for the erection of this contentious monument, ${ }^{2}$ herself became a source of extreme controversy. During her impassioned speech, held in front of a large and engaged audience including Holocaust survivors, their relatives and Jewish religious authorities, Rosh held up a tooth and informed those attending that the molar, which she had carried in her purse since 1988, would be embedded into the newly erected Holocaust memorial. Found seventeen years earlier at the site of the former extermination camp in Bełżec, Poland, the tooth was to be fixed into one of the monument's 2,711 pillars. This decision, according to Rosh, had been discussed with a rabbi and agreed upon with the monument's designer, Peter Eisenman, although the executive office of the Memorial Foundation had not necessarily been consulted. It sparked off a heated debate. ${ }^{3}$ Centred on the tooth, its unsettling presence at the Berlin ceremony, its daunting provenance and its problematic status as a remnant of an anonymous victim of the extermination camp, the immediate critical responses to Rosh's performance came from different directions and expressed very diverse concerns. All of these responses indicated, however, the profound political, symbolic and religious significance of the tooth, the fiercest opposition being voiced not so much by shocked and disgusted journalists and public intellectuals as by the representatives of various Jewish communities 
in Germany and Polish officials actively involved in the local commemoration of the former National Socialist camps.

Condemned by the president of the Central Council of Jews in Germany, Paul Spiegel, as an act 'bordering on blasphemy', the plan to bury the tooth of the Holocaust victim in the Berlin memorial, as well as the fact that it was left unburied for almost two decades, was a clear violation of Jewish religious law. To take a body part from its place of burial and to attempt to inhume it outside of the Jewish cemetery is patently against the norms of the Halakha. Moreover, the plan outlined for the future handling of the tooth skirted dangerously close to the cult of relics, which is strictly forbidden in Judaism. According to Albert Meyer, the chairman of Berlin's Jewish community, the implementation of Rosh's idea would therefore force its members to avoid visiting the Holocaust Memorial, which was, after all, not conceived as and should not be transformed into a Jewish cemetery. ${ }^{4} \mathrm{He}$ unequivocally castigated both the former treatment of the tooth and the intentions for its future handling. The Orthodox rabbi of the Jewish community of Berlin, Yitzhak Ehrenberg, who initially backed Rosh's plan, quickly withdrew his support in reaction to the widespread outrage caused by her address and proposed that the molar be buried with all due respect and deference to Jewish law at Berlin's Jewish cemetery at Scholzplatz.

Yet the Polish officials adopted a slightly different line of reasoning. Focusing on the highly problematic - if not criminal - nature of Rosh's decision to take the tooth from the site of the former extermination camp, Krystyna Oleksy, a representative of the State Museum Auschwitz-Birkenau, framed it as 'bordering on theft' and a desecration of the grave. ${ }^{5}$ The first director of the newly established museum-memorial site at Bełżec, Robert Kuwałek, also pointed out the almost unlawful character of the deed: 'It is strictly forbidden to take "souvenirs" whilst visiting our premises'; 'I have no knowledge of another instance of laying hold of such a peculiar souvenir by one of the guests.7 Thus, he both intimated and explicitly demanded that the tooth be returned to the former camp. Even though a few accounts exist of Holocaust survivors and relatives of Bełżec victims collecting bone fragments and human remains at the site and bringing them for burial in Israel or the United States, ${ }^{8}$ apparently unbeknown to Kuwałek at the time, the public display of the 'Jewish' molar taken from the former Nazi camp in Poland clearly overstepped too many boundaries. Ultimately, on 16 July 2005, the tooth was brought back to Bełzec and buried - in accordance with Jewish law and with the assistance of a rabbi - in a small box under one of 
the trees growing in the vicinity of the recently framed and protected mass graves of the victims of the extermination camp.

There are several reasons why I decided to quote the controversial story of the Bełżec molar as an entry point for the analysis of the material, political and affective afterlives of the human remains at this former National Socialist extermination camp. After all, the posthumous life of the tooth itself can be traced and investigated along various axes, both diachronic and synchronic, spatial and temporal. First, its unquestionable symbolic resonance and ability to mobilise diverse claims to sovereignty over the anonymous body part on religious, legal or political grounds allow an initial glimpse into the complex politics around the human remains from the Holocaust. In this respect, the struggle over the tooth could be perceived as a fascinating, if not somewhat perverse, example of the workings of the 'dead-body politics' as described by Katherine Verdery in her Political Life of Dead Bodies. Framed as a polysemic and multivocal 'symbolic vehicle' and the site of intersection of various constructions of meaning of both the molar and the past that it evokes, ${ }^{9}$ the tooth serves as a prism through which one could examine the dynamics of transnationalising Holocaust memory politics, within which all three interested parties, the 'Germans', the 'Jews' and the 'Poles', are pursuing and redefining their own, sometimes conflicting, agendas. In what follows, I will concentrate primarily on the trajectories of dead-body politics in post-war and post-1989 Poland, thus bringing my analysis closer to Verdery's reflection on the nationally based responses to the postsocialist transformation expressed in the treatment of the 'political corpses'. Notwithstanding this focus, the story of the Bełzec tooth clearly demonstrates that any purely national perspective on 'the politics of the Holocaust dead' is virtually impossible. This holds true in the case of Poland, just as is the case in Germany.

Second, the focus on the controversies surrounding the handling of the molar provides an interesting venture point into the following debate on the problematic status of the human remains resulting from the Holocaust. Framed, at times implicitly, through the language of blasphemy, idolatry, desecration and looting, the tooth became a battlefield of conflicting and shifting 'articulations', both discursive and those established through practices evolving around it. ${ }^{10}$ As a result, the discussions about the tooth's past and future did not so much stabilise its meaning as contribute to its profound ambivalence, blurring somewhat the distinctions between its various meanings and 'usages'. The molar transpired 
to be, at the same time, a relic and a trophy, a souvenir and corpus delicti, a subject to be literally and symbolically reburied, a private possession and national property. ${ }^{11}$ Building upon the ideas of Deborah Posel and Pamila Gupta, I would like to provisionally attribute this ambivalence to the specific ontology of the human remains, described by the authors of 'The Life of the Corpse' in terms of their 'dualistic life'.

'As a material object, on one hand, and a signifier of wider political, economic, cultural, ideological and theological endeavours, on the other', the corpse indeed evades any stable and unambiguous articulation. ${ }^{12}$ The different though overlapping trajectories of the material and political afterlives of the Bełzec tooth, as an object and as a repeatedly revisited and reinvested 'symbolic vehicle', clearly testify to this. Moreover, the 'dualistic life of the corpse' could pertain to yet another unstable distinction, that of the 'object' from the 'subject'. ${ }^{13}$ This unsettling quality of the human tooth as being both a thing (carried for years in a purse) and a remnant of a once living human being, first and foremost, affectively fuelled the debate over the fate of the Bełżec molar. One could therefore see the ethically and aesthetically saturated problem of what is considered permissible and impermissible, thinkable and unthinkable with respect to the body part at its epicentre. Thus, an attempt to frame the various forms of engagement with the bones and ashes resulting from the extermination in the Nazi death camp in Bełzec through the conceptual prism of the 'uneasy objecthood/subjecthood' of human remains can be conceived as the main thread of this chapter. ${ }^{14}$

Third, the public resonance of Rosh's performance also serves to illuminate the complex 'spatial politics' at play with respect to the remains of the Holocaust victims. The radical out-of-place quality of the Bełżec tooth, suddenly displayed in Berlin at the 2005 celebrations, cannot be reduced merely to the violation of religious prohibitions. Here, the reactions of the Polish authorities seem particularly symptomatic. They certainly suggest the existence of a problematic dimension of the event vis-à-vis the dynamics of spatially mediated politics of the Holocaust dead in Poland. Hence, one could ask, how should such a strong critical response to the anticipated 'dislocated burial' of the Bełżec tooth be interpreted? What enabled the controversial travels of the molar from Bełżec to Berlin and back in the first place? What does Rosh's idea of giving the Bełżec tooth a proper burial in Berlin's purely symbolical necropolis say about the real cemetery at the site of the former Nazi extermination camp in 
Poland, at which the molar was found in 1988, 'sticking out of the sand among other teeth from Holocaust victims '? ${ }^{15}$

\section{Porous graves}

The analysis of early descriptions of the site, created and compiled right after the war, provides a strong entry point to the question outlined above concerning the spatial dimension of the affective, symbolic and political strategies constructed around the human remains resulting from the extermination at Bełzec, and their unsettling 'dualistic afterlife. Produced and gathered within the framework of the official investigation of the local agency of the Central Commission for the Investigation of the German Crimes in Poland, conducted between 1945 and 1946, these materials offer a detailed portrayal of the fate of the mass graves, bones and ashes of Bełzec victims, as well as of various practices revolving around them since 1943. According to the first on-site report written on 10 October 1945, the terrain of the former camp, where the extermination of almost 450,000 Jews occurred between March and December $1942,{ }^{16}$ was not only cluttered with rubbish, mutilated artefacts, broken glass, pieces of bricks and concrete, but had also been dug up greatly. Several deep pits were scattered around the northern and eastern area of the former camp, where it was believed the mass graves were located; the soil around them was covered with unearthed and abandoned skeletonised and decomposing human remains. As stated in the report, 'bones, sculls, vertebrae, ribs, femurs, jaws, women's hair ... as well as fragments of rotting human flesh, such as hands and lower limbs of small children, lie strewn around all over the dug-up terrain. Besides, tons of ashes from burned bodies and small pieces of cremated bones can be found everywhere on the dug-up ground. ${ }^{17}$ The overpowering stench of rotting human corpses hung heavily over the site.

Briefed by the representatives of the town's police that the pits had been dug up by local villagers searching for gold and other valuables allegedly hidden among and in the human remains, the investigating judge supplemented the list of queries to be raised during the questioning of the inhabitants of Bełżec and neighbouring towns and villages with a direct enquiry concerning the looting of the mass graves. ${ }^{18}$ As a result, the witnesses questioned offered very precise and often detailed answers, dispelling any doubts as to the responsibility of the local Polish residents for the devastation of the former camp's terrain. A rather vague but also extremely inclusive 
term, 'local people', repeatedly appeared in their statements. The grave-robbery, which began immediately after the Nazis in authority left Bełżec in early July 1943, following the disposal of the bodies and dismantling of the camp, ${ }^{19}$ could thus be depicted as a 'community enterprise. ${ }^{20}$ For, even though the looting of the camp site was not practised or accepted by all members of the local populace, it definitely took on the appearance of a phenomenon driven by a group mentality. A railwayman working at a train station near the camp testified that, 'Until spring 1943 the camp was liquidated, the crew departed and thereafter members of the regional and local populace came to the camp site and dug up the soil in search of valuables. ${ }^{21}$ The accounts collected since 2004 by the employees of the newly established Bełzec museum and interviews, which I conducted, ${ }^{22}$ also reaffirm this assumption. I quote sparingly: 'after the liberation local inhabitants and people from Bełżec's surroundings came here to find the gold. This activity expanded greatly'; ${ }^{23}$ 'half of [our city] was searching there'; ${ }^{24}$ 'I used to go there as well, just like the majority of my acquaintances. ${ }^{25}$ According to a local policeman, after the camp was liquidated '[local people] dug out single corpses, or sometimes mass graves containing several people ... They looked for golden teeth in the jaws. ${ }^{26}$

Moreover, many statements gathered during and after the Bełżec probe vividly portray the practices involved in seizing the legendary 'Jewish gold': ${ }^{27}$ the demolition of the built structures remaining at the site of the former camp, the burrowing of the area of the camp in search of the burial pits, the digging out of the corpses to divest them of gold teeth, the sifting through ashes to remove gold and prospecting the former camp's latrine in pursuit of abandoned valuables. '[W]ith the help of spades and with bare hands, kneeling on their knees, people would sift the sand mixed with burned human remains in order to find the gold, ${ }^{28}$ admitted an informant who personally participated in the activities, which were at that time, apparently, almost entirely domesticated. Another person recounted: 'At that time, but also in the following years, it was normal and natural that after school a great majority of the pupils (not all of them) would go in a group to the site of the former camp, where they undertook the searches for the valuables'. Adults, he said, were also prospecting the site, transforming the grave-robbery into a business-like activity: 'Plunderers would sell the gold to real wholesalers of this business ... Bełżec wholesalers would then normally recast the gold into ingots and in this form sell it in Kraków. ${ }^{29}$ 
Clearly, intervention by SS officers only temporarily suspended their activity; they immediately reacted to the alarming news from Bełżec and decided to erect a farmhouse for a Volksdeutsch man and his family at the former camp as a means to protect its terrain from Polish villagers who unearthed the hidden mass graves, which were seemingly not hidden carefully enough. The looting resumed directly after the escape of the guards in the summer of 1944 and went on practically uninterrupted for years. Even the efforts sporadically undertaken by the local police to put an end to this practice - which was penalised under Polish criminal law - failed. ${ }^{30}$ 'When one succeeded in chasing away a group [of diggers], another one appeared straight away, ${ }^{31}$ stated the town's policeman, interrogated in 1945. Jan, who in 1958 worked in Bełzec in the vicinity of the camp, told me that, at that time, there was still clear evidence that digging had taken place at the camp and that human remains, ashes and bones were scattered over its terrain. He also discovered small piles of sand in a nearby forest, which, according to the information he was given, had been brought from the burial grounds and sifted through in the forest to prevent discovery by the police. ${ }^{32}$ Yet, until the late 1950 s no grave-robber, or 'cemetery hyena' as they were occasionally referred to at that time, was brought to trial. The Regional Court in Lublin sentenced the first four looters from Bełżec in 1959 and 1960. ${ }^{33}$ As a result, the descriptions of the dug-up terrain of the former extermination camp could be found in the official documents of Jewish organisations and Polish governmental agencies up until the early 1960s and, considerably more rarely, in the Polish press.

In 1956 an article entitled 'Bełżec - a Gold Mine: A Report from an Empty Field, probably the first Polish interpretive gaze into the looting of the camp site, was published in the all-Poland weekly, Świat. Its author, Andrzej Muralczyk, depicted with great concern the practices evolving at the site of the former extermination camp and briefly summarised the transformative dynamics underlying its social and cultural afterlife: the transition from the era of extermination to, as he called it, 'the season of the hyenas.' 'Bełżec was a gold mine for the Reich ... The extermination camp did not exist any more, but Bełżec was still a gold mine. ${ }^{34}$ Pushing Muralczyk's valiant literary analogy to extremes, one could nevertheless say that while the dehumanising logic guiding the treatment of the 'Jewish corpses' remained almost unchanged, the approach to the mass graves differed radically. After exploiting the bodies of their victims to the most extreme level, the Nazis undertook every effort to dispose of the traces of their crimes. The corpses of the people killed in Bełżec 
were buried, then exhumed, cremated and buried again. Afterwards, a pine forest was planted on the terrain of the former camp. The main objective of the Nazis was, after all, to remove any visual hint of the graves being, indeed, mass graves. Conversely, the post-war Polish 'hyenas' relied first and foremost on their porosity in order to reach their objectives.

The endeavour to theoretically frame these early activities evolving around the human remains of the Bełżec extermination camp is not an easy one. Despite the assumption held by many anthropologists that the universally shared respect towards one's own dead can take very extreme forms (like, for instance, endocannibalism or, indeed, grave-robbery), ${ }^{35}$ there is no existing ethnographic study that presents a convincing argument to suggest that this kind of engagement with corpses was culturally permissible in twentieth-century Poland. On the contrary, the sanctity of graves and cemeteries, as well as the very ambivalent status of the dead body, were wellestablished cultural conventions, symbolically and affectively structuring the handling of human remains. Thus, the fact that the grave-robbery involved only a small minority of Poles living in the vicinity of Bełżec and, for that matter, all Nazi extermination camps in Poland, ${ }^{36}$ and was not representative of Polish society as a whole, does not render it less disturbing. Neither does the existence of other accounts of lootings of the graves of victims of mass violence occurring across cultures and geographies exempt scholars from having to analyse the culturally and historically specific dynamics of those activities whenever they occur on such a large scale.

By the same token, the comparison drawn by some Polish historians between the post-war robberies of German graves on the so-called 'recovered lands' and the lootings of the camps in which a large majority of Polish Jews was killed is, in my opinion, somewhat misleading. ${ }^{37}$ For it not only blurs the distinction between the pre-war grave of a defeated 'enemy' and the mass grave of a brutally murdered 'fellow citizen', it also obscures the difference in the politi$\mathrm{cal}$ and affective economies guiding the treatment of their remains. Moreover, the historical analyses of the grave-robbers' activities provided in recent years by Polish scholars focus primarily on the broader context of the Second World War and the effects of long-term German occupation, ${ }^{38}$ which enabled and domesticated such behaviours, and rarely on the on-site activities themselves. ${ }^{39}$ Additionally, by designating extreme poverty, wartime demoralisation, the omnipresence of theft and the normalisation of death and dying, as well as post-war political and social chaos and resulting impunity, as the 
primary conditions of possibility of the grave-robbery, they render a theoretically informed analysis of the looting of the camp sites somewhat elusive. Much more plausible seems the thesis advanced by Jan Gross and Irena Grudzińska Gross in Golden Harvest, that not only greed and wartime demoralisation, but also sharp cultural and political divisions in pre-war Polish society, the legacy of Polish anti-Semitism and clear separation between 'Polish' and 'Jewish' war experiences, prepared the ground for these activities. ${ }^{40}$ Less convincing is the conceptual juxtaposition proposed in Golden Harvest of the looting Polish villager with Zygmunt Bauman's modern, rational 'gardener' methodically ridding his surroundings of every trace of the people 'considered weeds.' ${ }^{4}$

Therefore, building upon the ideas developed by Simon Harrison in Dark Trophies: Hunting and the Enemy Body in the Modern War, ${ }^{42}$ I would rather see the grave-robbery resulting from radical shifts in the frames of permissibility/impermissibility with respect to the bodily remains of the Jewish Poles as an example of an 'interstitial practice. ${ }^{43}$ This concept, which Harrison refers to as historically recurrent patterns of violent behaviours towards an enemy's corpse accompanying warfare conflicts, such as trophy-taking, robbing of body parts or mutilation, denotes a collective 'deviant or transgressive activity produced by transporting schemas from one domain of social interaction into another. ${ }^{24}$ Interstitial practice is thus a highly problematic and - mostly - culturally prohibited outcome of the 'misapplication' of cultural metaphors whereby conduct acceptable to one social realm is restructured in a different social context, whereupon it evolves and becomes normalised in anomalous conditions. Interpreted by Harrison as a form of violence perpetrated across cultural, class or, most often, racial lines, trophy-taking develops from a taboo-breaching conflation of war-waging and practices of hunting resting upon, and performatively leading to, the conceptual transformation of the enemy and (most often) his bodily remains from human into animal. Though Harrison's fascinating analysis of the racialised logic of dehumanisation visited upon remains of the 'other' is not entirely applicable in the context of the lootings of the extermination camp's mass graves - where the objects found in mass graves functioned not so much as trophies but as commodities - it certainly can provide a theoretical framework to conceptualise those activities.

The hierarchisation of nationalised deaths - even if not justified in strictly racial term ${ }^{45}$ - certainly served to structure the perceptions of and affective dispositions towards Jewish victims of the 
extermination camp among the inhabitants of Bełżec and the neighbouring villages. This was preconditioned by the pre-war othering of the 'Jew' as culturally distant and economically threatening, - radically deepened by the wartime separation of the 'Polish' and 'Jewish' orders of death and dying that resulted from the exterminatory politics of the occupying forces. The daily observation of the extermination process and (as emphasised by all interviewed witnesses) the troubling long-term sensory participation in its outcomes, which increased greatly when the method of exhuming and burning the corpses had been implemented, must have contributed to the radical distancing from and dehumanisation of the 'Jewish other'. It probably also 'aesthetically' prepared the ground for the following 'visits' to the camp site and digging among the decomposing human remains. On the other hand, the fact that the local residents definitely profited financially from the functioning of the extermination centre, for instance by trading food and liquor or, in the case of females, providing sexual services ${ }^{46}$ in exchange for the 'Jewish' gold and valuables brought from the camp by the guards, had an effect on the framing of the bodily remains resulting from the nearby extermination centre.

Thus, by locating these earlier activities in the broader context of the economically beneficial dimension of the Holocaust for Polish society, ${ }^{47}$ one could see them as merely one of many forms of the widespread wartime and post-war practice of 'repossession of the Jewish property. ${ }^{48}$ This is, in my opinion, exactly the cultural metaphor that provided the conceptual and affective framework within which the 'interstitial practice' of grave-robbery could develop, thoroughly blurring the distinction between the reappropriation of 'post-Jewish' property, as it was commonly referred to even during the war, and the treatment of the 'Jewish corpse'. In this context, one statement put forward by a female inhabitant of Bełżec seems particularly emblematic: 'After the war the terrain of the camp was haunted by the seekers of the post-Jewish gold and valuables. ${ }^{39}$ This suggests a radical emotional and conceptual detachment from the humanity of the desecrated Jewish bodies buried on its terrain.

Hence, unlike in the case of trophy-taking where the enemy's body was handled in a way resembling the treatment of the cadaver of hunted game (a trophy), the 'Jewish' bodily remains were seen merely as a commodity or as a depository of 'Jewish gold'. Consequently, it is not the human/animal (in)distinction - central to Harrison's analysis of the 'interstitial practice' of robbing the body parts of the dehumanised combat opponents - that is the crucial 
point here, rather it is that the looting of the camp site was greatly dependent on the perception of the remains of the murdered subjects as mere objects. Thus, the above-mentioned unsettling and irreducible quality of bodily remains, described by Joost Fontein and John Harries as 'uneasy subjects/objects, ${ }^{50}$ was denied by the actual forms of engagement with victims' flesh, bones and ashes developing at the site of the former extermination camp. ${ }^{51}$ This radical 'objectification' of the human remains, which deprived them of the 'human' component, had a dual effect: rendering the mass graves porous, and the Bełżec dead 'unburiable. 52

\section{The buriable dead}

It is unquestionable that the rites of separation for the treatment of symbolically and politically charged human remains were central in twentieth-century Poland. Even in the face of the consequences of mass death brought about by the Second World War, whose numerous mass graves, burial pits and countless provisionally buried corpses spread all over the war-torn country caused practical challenges, the cultural politics of burial did not undergo any major transformation. On the contrary, the dead-body politics around the victims of Nazism came to occupy a prominent position in legitimising the ideology of the new state apparatus. The practice of inhumation, bringing about the physical and symbolic separation of the living and the dead and the 'rearticulation' of the dead in their relation to the living, was considered the most respectful and politically efficacious way of dealing with the corpses, both individual and en masse. The political subjectification of the dead according to dominant interpretations of the recent past was also crucial for the treatment of the corpses coming out of the Nazi camps. As an example, one could consider the concentration and extermination camp Auschwitz-Birkenau, where, as early as 28 February 1945, one month after its liberation, a ceremonial burial of 470 of its victims took place. According to Marta Zawodna, this successfully established a new symbolic order, in which not only the humanity and sanctity of the dead of Auschwitz-Birkenau were asserted, but they were also framed (or better put, reappropriated) politically. ${ }^{53}$ Moreover, as Zawodna claims, the religiously framed inhumation of the corpses, even if it did not put an end to the looting of the camp site, once and for all ethically and affectively delegitimised the activity of the grave-robbers plundering Birkenau. 
For a variety of reasons, no similar operation of rearticulating the human remains through the practices of political burial was mounted at Bełżec at that time. Certainly, the lack of 'Polish' victims played a critical role in the symbolic marginalisation of the site, a fate similar to that of all Nazi extermination centres, which did not (simultaneously) perform the function of concentration camps. ${ }^{54}$ In this respect, the selective politics of burial reflected the constitution of gradually homogenising post-war Polish society, 'the hierarchy of dead bodies mirroring the political hierarchy of the Polish state, ${ }^{55}$ to slightly paraphrase Finn Stepputat. Even though the communist-dominated state administration granted relative autonomy to various Jewish organisations in the early post-war years, the lack of financial resources and constant struggles over the sovereignty of Auschwitz-Birkenau and Majdanek with Polish political prisoners' organisations ${ }^{56}$ hugely restricted the possibility of decisive on-site action. ${ }^{57}$ The fact that there were only two known survivors of the camp, Rudolf Reder and Chaim Hirszman, greatly reduced the chances that effective lobbying for the commemoration of the camp would take place on behalf of its victims. As a result, apart from provisional excavations carried out within the framework of the official investigation conducted at the site in 1945, no research was undertaken in order to bring to light and protect the mass graves at Bełzec. Moreover, no evidence exists to suggest that any clean-up or inventory works were performed at the site before the mid-1950s.

In 1954, on the initiative of the governmental Council for the Protection of the Memorials of Combat and Martyrdom, responding to the demands of Jewish organisations in Poland, the camp was fenced in for the first time..$^{58}$ It was probably at this point that a small crypt was erected in the northern area of the camp, in which the bones and artefacts found on its territory were assembled. Yet, as Jan informs me, the small doors leading to it were left unlocked and, consequently, the numerous skulls gathered in the crypt were easily accessible. The fact that the human remains scattered over the territory of the camp surrounded the substitute 'grave' only added to its incongruity. As reported by the representatives of the council sent to Bełżec in May 1962 - when the decision to commemorate the former camp was finally reached - the traces of digging were still visible at the site. ${ }^{59}$ Therefore, the idea to seal off the existing burial pits by covering them with concrete slabs (as was later the case in Treblinka) was presented as the recommended course of action. ${ }^{60}$ Additionally, a forester's lodge was erected at the former camp, its 
inhabitants charged with the task of protecting the site from further profanation.

The material, symbolic and political transformation of the remains of the Bełżec victims into 'dead (political) subjects, ${ }^{61}$ to borrow Fontein's phrase, took place in 1963. On 1 December, the memorial landscape fashioned by Henryk Jabłuszyński was opened to the public. Designed in the form of a complex of monuments, obelisks, urns and a mausoleum housing the remains of victims of the camp (built over the crypt described above), the landscape was formed to mark the key sites of the extermination centre, such as the gas chamber and burning pyres, and to portray the monstrosity of the events that unfolded at Bełzec. These were framed through a figurative representation of its victims, designed by Stanisław Strzyżński: a sculpture representing the disfigured bodies of two men, one apparently dying, in their last act of human solidarity. The wrongly located mass graves were surrounded by a concrete kerb and covered with a raised lawn. The idea to seal them off was ultimately not implemented. Additionally, the fact that some of the burial pits were not even contained within the fenced-in terrain of the memorial site clearly testified to their purely symbolic character. Nevertheless, the memorial landscape, dedicated to the 'victims of Nazi terror', as declared in the inscription engraved on the central monument, unambiguously rearticulated the human remains that were now at least provisionally separated from the living. In line with contemporary state ideology, entangled in broader geopolitical tensions, the dead were both subjectified into a broad community of victims, somewhat lacking a clear national identity, and remade into politically potent reminders of the threat associated with 'Western imperialism. ${ }^{62}$ It was thus, most probably, the rebuilding of the Bundeswehr (1955) and the approaching expiry in West Germany of the statute of limitations for murders committed during the war $(1965)^{63}$ that acted as an incentive to rehumanise the Bełżec dead by making them 'appropriately meaningful. ${ }^{64}$

The belated and makeshift character of the spatial and symbolic strategies constructed around the bodily remains resulting from the extermination at the camp soon turned against itself. As a result of the process of natural exhumation, small bone fragments and complete bones began to resurface, pointing out the highly problematic nature of their handling. In 1988, as the history of the Bełżec tooth clearly shows, they were still lying on the ground and could easily be picked up. Moreover, the overall neglect of the site, owing to its low position in the hierarchy of Second World War commemoration 


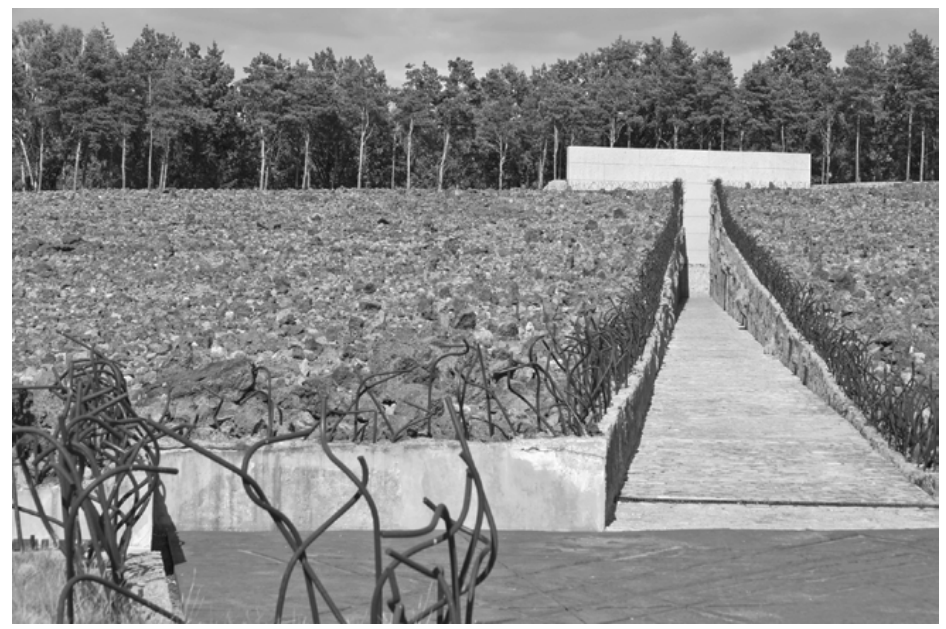

Figure 2.1 Museum-Memorial site at Bełżec

in Poland and its - one can assume - problematic status vis-à-vis the 'local populace', began to draw attention and criticism from a number of sources. In 1994 an Israeli citizen, outraged by the state of the site and the anti-Semitic inscription on the monument, alerted international Jewish organisations and the Israeli state. Consequently, in 1995 a formal agreement was reached between the US Holocaust Memorial Museum in Washington and the Polish government, obliging the Polish side to redesign the memorial landscape at Bełżec. Soon thereafter, a closed national competition was announced. The winning project, by Polish sculptors Andrzej Sołyga, Zdzisław Pidek and Marcin Roszczyk, was unveiled in the summer of 2004 in the presence of high-ranking officials from Poland, Israel and the United States, Jewish religious authorities from Poland and abroad, and the Holocaust survivors.

The radical, if not somewhat paradoxical, shift in the spatially mediated politics around the remains resulting from the extermination at Bełzec, embedded unquestionably in a broader transformation of the approach to the Holocaust in post-1989 Poland, manifested itself, first and foremost, in the explicit emphasis on the Jewish identity of the dead. This was entirely erased form the 1963 memorial. The project, aimed at honouring the victims according to their cultural and religious traditions, was therefore to be finalised in deference to Jewish law. The rabbinical prohibition against removing or disturbing the graves resulted in their full protection, for instance 
sealing them off once again on a permanent basis. As the project reads, the whole area of the mass graves was 'covered with a special, heavy-duty geotextile material ... covered with sand and drainage pipes to divert water away from the surface and, in turn, covered with the industrial slag, ensuring that the bone fragments would not resurface. ${ }^{65}$ Only a narrow interstice, free from human remains, leading the visitors through the burial grounds from which the path is separated by massive walls, enables access to the cemetery. The implementation of these measures was, this time, preceded by archaeological research conducted in Bełzec from 1997 to 2002 by Polish archaeologists employing a very traditional methodology in order to locate the graves - manual drilling penetrating the ground to a depth of around six metres. ${ }^{66}$ This is clearly a fundamental breach of the norms of Halakha. ${ }^{67}$ Moreover, the excavations were not conducted under rabbinical supervision. The human remains unearthed outside the burial area were simply packed in plastic bags and reburied in one of the thirty-three mass graves uncovered during the excavations. ${ }^{68}$

Interestingly, it was not so much the highly problematic archaeological research as the construction of the interstice cutting across the burial grounds that in 2002 served as an incentive for the Jewish religious authorities and the relatives of the Bełzec victims to oppose the memorial project. Voiced most forcefully by the New York rabbi Avi Weiss, the objections pertained to the disrespectful treatment of the 'tortured and mute remains' of the Bełzec dead framed through the language of desecration. ${ }^{69}$ According to Weiss, all of the soil in the former camp was 'composed of our people', whose peace was yet again being disturbed by the extremely invasive spatial intervention. Yet neither his journey to Poland in order to block the construction of the memorial, nor the lawsuit filed against the American Jewish Committee (which in 2002 got involved in the project to commemorate Bełżec and replaced the US Holocaust Memorial Museum in its function) was fully successful. Nevertheless, the Polish authorities ensured that the further work on the memorial remained under the strict rabbinical supervision of the chief rabbi of Poland, approved also by the chief rabbi of Israel and the Ultra-Orthodox chairman of the Committee for Preservation of Jewish Cemeteries in Europe, Elyakim Schlesinger. ${ }^{70}$ It was, therefore, based on close cooperation between the designers of the memorial landscape and the representatives of the Jewish Cemeteries Rabbinical Commission in Poland, who made sure that the sanctity of the human remains 
buried at the former camp was protected in line with the Orthodox interpretations of the Halakha. The victims of the camp were, as a result, perceived through the frame of religious martyrdom. ${ }^{71}$ This religious monopolisation of the Bełżec dead - essentially in line with the intentions of the Polish side - contributed greatly to their renewed subjectification into a fixed identity, this time that of the Jewish victims of the Holocaust - and less so that of Polish citizens who also happened to be Jewish. ${ }^{72}$

In many ways, the spatial outcome of the dense and controversy-ridden politics surrounding the Bełżec dead mirrors and reinforces this unambiguous assertive reinscription of identity. Framed through the presence of religious symbols, such as the menorah or the Star of David, as well as a wall covered with a long list of 'typical' Jewish names located at the end of the controversial interstice, the memorial landscape unequivocally transforms the site of the former camp into a Jewish cemetery and rearticulates the human remains resulting from it into members of a clearly defined (and somewhat stereotypically reproduced) community, to whom a proper burial is finally being given. The sense of religiously and politically saturated closure is exacerbated here by a permanent and technologically ensured closing off of the bodily remains of the camp's victims on the one hand, and by a careful erasure of all traces of its difficult post-war history on the other. ${ }^{73}$ As a result, while suggesting the resolution of the unsettled relations between the living and the dead, the transformative process of burial leaves the identity-based division between 'Jews' and 'Poles' virtually intact; the 'Poles' are properly burying the 'other. ${ }^{74}$ The sacralisation of the site, which strategically blocks any further polemical intervention, goes hand in hand with a hegemonic rearticulation of its Polish-Jewish past facilitated by the very logic of reburial: human remains are once more animated and radically redefined so that the legacy of their previous material and political posthumous lives can finally be put to rest, without being explicitly problematised.

Could this perhaps be one of the reasons for the strong reaction provoked by the sudden emergence of the tooth at the Berlin ceremony in 2005, bringing back the memories of the complex 'dualistic afterlives' of the remains resulting from the extermination at Bełzec - the lootings and the site's long-lasting neglect - and the obvious implication that the graves might had been sealed off too prematurely? 


\section{'Excessive reminders'}

The ability of human remains to evade, problematise or radically question the material, symbolic and political strategies constructed around them has for some time now become subject to scholarly interest. Theorised in terms of the 'agency of bones' and dead bodies, founded both in their 'affective presence' as extensions of once-living human beings and in their materiality as objects or, more recently, in their constantly changing material properties as things, ${ }^{75}$ the capability of bodily remains not only to animate but also to 'act back ${ }^{36}$ and subvert the spatially mediated dead-body politics lies, as the case of the Bełżec tooth exemplifies, in their constitutive excessiveness, symbolic and literal. According to Harries and Fontein, precisely because they are excessive, uneasy objects/subjects, human remains defy not only political and symbolic endeavours to make them 'appropriately meaningful', but also 'techniques of subjectification and objectification, ${ }^{77}$ rendering any hegemonic closure of the meaning of the dead, if not impossible, then at least open to contestation. They are, from this perspective, neither entirely mute (Avi Weiss), nor fully containable - their unexpected materialisations, uncontrollable travels and relentless transformations are an integral part of their material, affective and political afterlives.

The controversial journeys of the Bełżec molar provides just one of many examples demonstrating how human remains can perform their unobtrusive agency and act as 'excessive and stubborn reminders' that, in Shela Sheikh's words, have 'the potential to resist identification ... burial, and sacralization. ${ }^{78}$ An agency that presents both symbolic and practical challenges to the politics surrounding the Holocaust dead and suggests a problematic dimension of the redemptive closure spatialised at the former camp - although ultimately arrested and pacified through its 'proper', itself somewhat belated, ${ }^{79}$ inhumation. It can also take the form of affective circulation of ghost stories and uncanny narratives, resting upon the 'excessive potentiality' pertaining to the 'human' dimension of bodily remains ${ }^{80}$ which bears witness to the unresolved legacies of violence and neglect. In this respect, the long history of grave-robbery resulting from the radical objectification of the Bełżec dead seems to provide a particularly fertile ground for the proliferation of such narratives. The tentative accounts of sudden deaths or instances of madness among the most notorious 'cemetery hyenas, ${ }^{81}$ of the unexpected and severe illnesses suffered by their offspring, of the inability to 'make money' on the 'Jewish gold' and of the extremely short lifespan of the animals bought from it, ${ }^{82}$ recounted in recent years by the inhabitants 
of Bełzec, clearly testify that the local populace 'haunting' the terrain of the former camp in search of gold is, in turn, haunted back. The uneasiness vis-à-vis the practices perpetrated on the bodily remains of its victims is also expressed in the unsettling encounters with nonfigurative ghosts also experienced by representatives of the second generation. As an example, one can quote the story of a middle-aged man who, in 2005, arrived at the newly opened museum in order to return a golden ring, given to him by his grandmother, after a young, beautiful 'Jewess' visited him in a dream and ordered him to do so. ${ }^{83}$

This belatedly transformed affective disposition towards the Bełżec dead - reinscribing them with posthumous 'subjectivity' and the ability to act back - nevertheless has very limited critical potential. Centred on the problematic dimension of the 'repossession' of the property of the victims and the restoration of the sense of justice shaken by the effective and long-lasting robbery, these narratives paradoxically reproduce the violence-generating polarised identity politics underlying the treatment of the bodily remains of Bełzec victims. The score being settled between 'Jews' and 'Poles' is strongly implied by the disturbingly phantasmic reference to the 'Jewish gold' and the 'beautiful Jewess. Here, a statement by an elderly female inhabitant of Bełżec seems (again) particularly emblematic: when the Jewish ghosts appear, 'one has to cross oneself aloud, then the evil will go away. They were not baptised, that is why they return.84 ${ }^{84}$ The legacy of the exclusive othering of the 'Jew' remains remarkably intact.

The lingering, affective presence of the dead evoked by the uncanny narratives recounted by those dwelling in the proximity of the former camp and the mass graves of its victims also has, however, a much more disturbing 'corporeal' counterpart, insusceptible to the identity-based politics of the dead. As shown in the work of Polish artist and scholar Elżbieta Janicka, the photographic series The Odd Place (2003-04), the problem of the persistent endurance of the traces of the extermination at the sites at which it took place does not, after all, have a purely symbolic character. In six largeformat photographs taken at the former Nazi death camps in Poland (Auschwitz-Birkenau, Majdanek, Treblinka, Sobibór, Chełmno and Bełzec), Janicka captured the air drifting above their grounds, penetrated for years by the ashes resurfacing from the porous graves. The images showing white surfaces enclosed within black frames and supplemented with inscriptions stating the exact dates when the pictures were taken 'represent' the tacit circulation of the burned remains above the post-Holocaust landscapes. At the same time, the work points out the ongoing relationship between the living and the 
dead mediated and sustained through this uncontrollable circulation. 'The ashes flow in the air. We breathe this air ... The ashes are in the soil, in the rivers, on the meadows, and in the forests - subjected to constant recycling, in which we participate, ${ }^{35}$ the artist states.

Interestingly, the thesis advanced in the artwork has found 'confirmation' in reality. When archaeological research was conducted at Bełżec in the late 1990s, it was discovered that the forester's house erected at the site in the 1960s was located in the immediate vicinity of one of the mass graves. The well used by its inhabitants was tested and it was confirmed that the water was contaminated, as one of the residents assumed, by the decomposition products from human corpses, which had penetrated the groundwater. ${ }^{86}$ The many families dwelling in the house for almost four decades had been drinking water polluted by the bodily remains of the Bełzec dead. This extreme example thus provides an enormously appealing mirror image of the sensory participation of the local populace - for many months exposed to the stench of the burning corpses - in the extermination process, now taking the form of unintentional, corporeal partaking in their decay. It nevertheless perfectly captures the logic of Janicka's argument: the constant, uncontainable flow of ashes and the seepage of bodily fluids of Bełzec victims establishes an exchange between the dead and the living, 'Jews' and 'Poles', adding a new dimension to their unsettled relations. Described by the artist in terms of the impossibility of a complete and permanent burial of the victims of the camp, the material circulation of their remains, which resists and blurs the identity-based divisions separating them, designates the 'Poles' - at least as processual and relational bodies - to act as sarcophagi for the otherwise unburiable dead.

\section{Notes}

1 I am indebted to the Alexander von Humboldt Stiftungand the Vienna Wiesenthal Institute for Holocaust Studies (VWI)for their generous support of the research built upon by this chapter.

2 For a detailed history of the fierce political debates surrounding the Berlin Holocaust Memorial, see 'Germany's Holocaust memorial problem - and mine', in J. Young, At Memory's Edge: After Images of the Holocaust in Contemporary Art and Architecture (New Haven, CT and London: Yale University Press, 2000), pp. 184-223. This addressed both the contested idea of commemorating the Jewish victims of National Socialism in Berlin and the form such a memorial should take, initiated in the late 1980s by Lea Rosh and Eberhard Jäckel but not resolved until 1999 when the Bundestag finally voted to build the monument. 
3 J. Bisky, 'Die Beerdigung eines Zahns', Süddeutsche Zeitung, 13 May 2005. URL: www.sueddeutsche.de/kultur/holocaust-mahmnal-in-berlin-diebeerdigung-eines-zahns-1.415866 (accessed 5 December 2013).

4 C. Schulze, 'Lea Rosh brüskiert Jüdische Gemeinde', Spiegel Online, 11 May 2005. URL: www.spiegel.de/kultur/gesellschaft/holocaustmahnmal-lea-rosh-brueskiert-juedische-gemeinde-a-355600.html (accessed 5 December 2013). In line with the Halakha, the entire body of the deceased is considered a unity created in the image of God. Consequently, any removed part of the body should be subject to burial; only in this way can the bodily resurrection of the person in her entity be secured. The place of burial of body parts is, therefore, also treated as sacred. See, for instance, M. Lamm, The Jewish Way in Death and Mourning (New York: Jonathan David Publishers, 2000).

5 ZB, 'Der Lea Rosh-Skandal', Berliner Kurier, 13 May 2005. URL: www. berliner-kurier.de/archiv/es-war-eine--grausamkeit--den-backenzahnmitzunehmen--die-vize-direktorin-der-gedenkstaette-in-auschwitz-istueber-den-vorfall-schockiert-der-lea-rosh-skandal,8259702,4098206. html (accessed 5 December 2013).

6 Quoted in Deutsche Presse-Agentur, 'Lea Rosh gibt Backenzahn an Belzec züruck', Spiegel Online, 13 May 2005. URL: www.spiegel.de/politik/deutschland/mahnmal-streit-lea-rosh-gibt-backenzahn-an-belzeczurueck-a-356057.html (accessed 5 December 2013).

7 Quoted in P. Reszka and S. Szewc, 'Liczy się szacunek', Gazeta Wyborcza Lublin, 16 May 2005, p. 2.

8 See, for instance, A. Elsner, 'Memorializing those murdered at Belzec', 1995. URL: http://remember.org/educate/belzec.html (accessed 6 December 2013).

9 K. Verdery, The Political Life of Dead Bodies: Reburial and Postsocialist Change (New York: Columbia University Press, 1999), p. 27.

10 I refer to the concept described by Elizabeth Hallam. See E. Hallam, 'Articulating bones: an epilogue', Journal of Material Culture, 15 (2010), 465-92.

11 By taking the tooth from the site of the former camp, Lea Rosh to some extent violated the legally binding and commonly accepted rule according to which 'no "property interest" exists in a dead body'. Essentially, a body is irreducible to and should not become a private possession of another individual.

12 D. Posel and P. Gupta, 'The life of the corpse: framing reflections and questions', African Studies, 68 (2009), 299.

13 See H. Williams, 'Death warmed up: the agency of bodies and bones in early Anglo Saxon cremation rites', Journal of Material Culture, 9 (2004), 263-91.

14 Here, I build upon the ideas regarding bones as 'uneasy objects/subjects' developed by the representatives of the 'Bone Collective'. See, for instance, C. Krmpotich, J. Fontein and J. Harries, 'The substance of bones: the emotive materiality and affective presence of human remains', Journal of Material Culture, 15 (2010), 371-84; J. Fontein and J. Harries, 'The vitality and efficacy of human substances', Critical African Studies, 5 (2013), 115-26. 
15 Quoted in K. Connolly, 'Jews angry over memorial plan for death camp tooth', The Telegraph, 13 May 2005. URL: www.telegraph.co.uk/news/ worldnews/europe/germany/1489942/Jews-angry-over-memorialplan-for-death-camp-tooth.html (accessed 5 December 2013).

16 R. Kuwałek, Obóz zagłady w Bełżcu (Lublin: Państwowe Muzeum na Majdanku, 2010), pp. 170-2.

17 Protokół z oględzin obozu śmierci w Bełżcu, 10 October 1945, in D. Libionka (ed.), Obóz zagłady w Bełzcu $w$ relacjach ocalonych $i$ zeznaniach polskich świadków (Lublin: Państwowe Muzeum na Majdanku, 2013), p. 123.

18 Question number 8 (of 9) was: 'When did the local population start digging up the terrain of the camp looking for gold and precious stones left by the murdered Jews?' Akta $w$ sprawie zbrodni niemieckich $w$ obozie śmierci w Betzcu, 1945-1949, AIPN, OB. 2, 127-8.

19 S. Berger, Experten der Vernichtung: Das T4-Reinhardt-Netzwerk in den Lagern Belzec, Sobibor und Treblinka (Hamburg: Hamburger Edition, 2013), p. 193.

20 In the article 'On the clearing of the post-camp world', sociologist Marta Zawodna conceptualised the practice of 'digging in the human remains' at the site of the former Auschwitz-Birkenau camp in terms of a 'peculiar social order' created by the local populace. See M. Zawodna, 'O porządkowaniu poobozowego świata: Sposby postępowania ze szczatkami ludzkimi na terenach byłego KL Auschwitz-Birkenau od momentu ostatecznej likwidacji obozu do powstania muzeum', Zagłada Żydow: Studia i materiały, 8 (2012), 173.

21 This is the statement by Alojzy Berezowski on 5 November 1945 in Libionka, Obóz zagłady w Bełźcu, p. 194.

22 Two of my respondents, whom I interviewed in Bełżec in September 2014, described the mass character of the looting, but nevertheless delegated the responsibility to the inhabitants of towns and villages other than Bełżec. Interview conducted with Mieczysław, 25 September 2014; Interview conducted with Franciszka, 25 September 2014.

23 Relation 27, anonymised, MMPB.

24 Relation 15, anonymised, MMPB.

25 Relation 19, anonymised, MMPB.

26 Statement by Mieczysław Niedłużak, 17 October 1945, in Libionka, Obóz zagłady w Bełźcu, p. 185.

27 The representatives of the local populace were well aware that the possessions of those brought to the camp were collected by the Nazis and that the bodies of those gassed were examined in search of gold teeth and valuables hidden in bodily orifices. Nevertheless, the searches for 'Jewish gold' were undertaken and, in many cases, proved successful. Relation 15, anonymised, MMPB.

28 Relation 15, anonymised, MMPB.

29 Relation 16, anonymised, MMPB.

30 The profanation of human remains and burial sites was a crime penalised under pre-war criminal law (Art. 168). On 13 June 1946, a 'Decree on crimes particularly dangerous during the reconstruction of the State' 
was passed, which increased the maximum penalty for the profanation of graves from two to five years' imprisonment or, in cases of crimes committed in particularly aggravating circumstances, to ten years' imprisonment (Art. 26, 27). Dziennik Ustaw z dnia 12.07.1946. Nr 30, poz. 192.

31 Statement by Mieczysław Niedłużak, 17 October 1945, in Libionka, Obóz zagłady w Bełźcu, p. 185.

32 Interview with Jan, conducted 23 September 2014.

33 The police investigations were also conducted in the early 1960s under the operational cryptonym 'Undertakers'. Report by the Commander of Regional Police Department in Lublin, 12 February 1962, ROPWiM, syg. 52/5, 7-10.

34 A. Muralczyk, 'Bełżec: kopalnia złota - raport z pustego pola', Świat, 17 (1956), reprinted in D. Lis (ed.), Wokót 'Złotych żniw': Debata o książe Jana Tomasza Grossa i Ireny Grudzińskiej-Gross (Kraków: Znak, 2011), p. 53.

35 C. Levi-Strauss, Tristes Tropiques (London: Penguin Classics, 2012), p. 232.

36 R. Kuwałek, 'Obozy koncentracyjne i ośrodki zagłady jako miejsca pamięci', in F. Tych and M. Adamczyk-Grabowska (eds), Następstwa zagłady Żydów: Polska 1944-2010 (Lublin: Wydawnictwo Uniwersytetu Marii Curie-Skłodowskiej, Żydowski Instytut Historyczny, 2012), pp. 493-525.

37 M. Zaremba, Wielka Trwoga: Polska 1944-1947 - Ludowa Reakcja na kryzys (Kraków: Znak, 2012). See particularly the chapter 'Szaber' [Looting].

38 Zaremba, Wielka Trwoga; see also essays by Marcin Zaremba, Bożena Szaynok and Paweł Machcewicz collected in Lis, Wokół 'Złotych żniw'.

39 Martyna Rusiniak's works on Treblinka are an important exception. See M. Rusiniak, Obóz zagłady Treblinka II w pamięci społecznej (19431989) (Warsaw: Neriton, 2008).

40 J. T. Gross and I. G. Grudzińska Gross, Golden Harvest: Events at the Periphery of the Holocaust (New York: Oxford University Press, 2012).

41 Ibid., p. 41.

42 I am greatly indebted to John Harries for directing my attention to Simon Harrison's work.

43 S. Harrison, Dark Trophies: Hunting and the Enemy Body in Modern War (New York and London: Berghahn, 2014), p. 18.

44 Ibid., p. 189.

45 The workings of the pre-war dead-body politics, separating the 'Polish' and 'Jewish' corpses across religious and national lines, are described by Natalia Aleksiun. See N. Aleksiun, 'Christian corpses for Christians! Dissecting the anti-Semitism behind the cadaver affair of the second Polish Republic', East European Politics and Societies, 25:3 (2011), 393-409.

46 Gross and Grudzińska Gross, Golden Harvest; Interview with Mieczysław O., 25 September 2014.

47 This was recently brought to public attention by Andrzej Leder's Overdreamt Revolution and the collected volume The Keys and 
the Till (published in Polish as, respectively, A. Leder, Prześniona rewolucja: Ćwiczenia $z$ logiki historycznej (Warsaw: Wydawnictwo Krytyki Politycznej, 2014) and J. Grabowski and D. Libionka (eds), Klucze i kasa: O mieniu żdowskim w Polsce pod okupacja niemiecka $i$ wewczesnych latach powojennych 1939-1950 (Warsaw: Stowarzyszenie Centrum Badań nad Zagładą Żydów, 2014)).

48 J. Grabowski and D. Libionka (eds), 'Introduction', in Klucze i kasa: O mieniu żydowskim w Polsce pod okupacja niemiecka $i$ we wczesnych latach powojennych 1939-1950 (Warsaw: Stowarzyszenie Centrum Badań nad Zagładą Żydów, 2014), p. 20.

49 Relation 39, anonymised, MMPB.

50 Fontein and Harries, 'The vitality and efficacy', 120.

51 One could argue that the objectifying and dehumanising logic behind the treatment of the mass graves and the remains of the people buried at the site of the former camp - leading to the ultimate utilisation of their bodies - strongly resembled that visited upon them by the Nazis when the extermination centre was still operational. See, for instance, A. Strzelecki, 'The plunder of victims and their corpses', in Y. Gutman and M. Berenbaum (eds), Anatomy of the Auschwitz Death Camp (Bloomington, IN: Indiana University Press, 1998).

52 In Precarious Life, Judith Butler observes that the dead whose death is not acknowledged as death are, in principle, 'the unburied, if not unburiable'. See J. Butler, Precarious Life: The Powers of Mourning and Violence (New York and London: Verso, 2006), p. 34.

53 It is worth noting that the Jewish identity of the majority of the victims was not mentioned at that time. Later that year, on the initiative of the association of Polish former political prisoners, a cross bearing the inscription 'In the memory of our tortured brothers' was erected near the grave. See Zawodna, 'O porządkowaniu', 162.

54 In her study on the post-war debates surrounding former Nazi camps in Poland, Zofia Wóycicka posits that one of the reasons why, unlike the former concentration camps at Majdanek, Gross-Rosen, AuschwitzBirkenau and Stutthof, the camps of Chełmno, Bełżec, Treblinka and Sobibór were not commemorated was the fact that 'extermination camps were places exclusively associated with Jewish martyrdom'. See Z. Wóycicka, Arrested Mourning: Memory of the Nazi Camps in Poland, 1944-1950 (Frankfurt am Main: Peter Lang, 2013), p. 189.

55 F. Stepputat, 'Introduction', in F. Stepputat (ed.), Governing the Dead: Sovereignty and the Politics of Dead Bodies (Manchester: Manchester University Press, 2014), p. 7.

56 For a detailed analysis, see Wóycicka, Arrested Mourning.

57 In the following years, the Central Committee of Polish Jews and its successor, the Socio-Cultural Association of Jews in Poland, also strongly lobbied for the commemoration of the former extermination camps. In the case of Treblinka, those efforts proved partially successful. In 1947 the first competition for a memorial was announced; nevertheless the winning project was never realised. In the 1950s the association effectuated 
the laying of the foundation stone for the Treblinka memorial, which was finally erected in 1964. See Rusiniak, Obóz zagłady Treblinka II w pamięci społecznej, 37nn.

58 Informacje o działalności Rady w latach 1960-1969, ROPWiM $1 / 100,6-7$.

59 J. Kowalik and S. Guirard, Sprawozdanie z inspekcji b. obozów zagłady w Sobiborze i Betżcu, 7 May 1962, ROPWiM 52/6, 3-4.

60 Protokół z posiedzania ROPWiM, 18.05.1962, ROPWiM 1/2.

$61 \mathrm{~J}$. Fontein, 'Remaking the dead, uncertainty and the torque of human materials in northern Zimbabwe', in F. Stepputat (ed.), Governing the Dead: Sovereignty and the Politics of Dead Bodies (Manchester: Manchester University Press, 2014), p. 127.

62 Here, again, the parallels between the fates of all four extermination camps become visible: the first memorials were erected at Treblinka and Chełmno in 1964 and at Sobibór in 1965.

63 This is a thesis advanced by Robert Kuwałek. See Kuwałek, 'Obozy koncentracyjne'.

64 Posel and Gupta, 'The life of the corpse', 307.

65 Betzec: Nazi Death Camp (Vienna: Grasl, 2006), p. 25.

66 A. Kola, Betzec: The Nazi Camp for Jews in the Light of Archaeological Sources (Warsaw and Washington, DC: ROPWiM, 2000), p. 13.

67 According to the Jewish religious law, the body of the dead and the grave in which it rests should not be subject to any kind of disturbance, including exhumation or archeological research employing invasive methods. This was obviously the case in Bełżec where archeologists drilled into mass graves in order to determine their exact location. See, for instance, C. Sturdy Colls, Holocaust Archaeologies: Approaches and Future Directions (New York: Springer, 2015), pp. 66-9.

68 Bełżec 1997-98. Badania acheologiczne, MMP IV-41/1/2, 177.

69 A. Weiss, 'Let the victims of Bełżec rest in peace', Jerusalem Post, 14 August 2002, 4.

70 Information provided by Alexander Schwarz from the Jewish Cemeteries Rabbinical Commission in Poland. Interview conducted 22 September 2014.

71 M. Schudrich, 'Let Belzec victims finally rest in peace', 25 July 2003. URL: http://forward.com/opinion/7765/let-belzec-victims-finally-restin-peace (accessed 3 October 2015).

72 Thus, at the opening ceremony on 3 June 2003, Polish president, Aleksander Kwaśniewski, whose speech emphasised the double identity of the dead as 'sons and daughters of Israel, but also in an equal measure as children of Poland', nevertheless framed Bełżec as 'foremost a Jewish place of eternal rest', and not a site commemorating a common PolishJewish tragedy - or a tragedy that would necessitate a radical rethinking of the identity divisions that brought it into being. See A. Kwaśniewski, in Bełżec: Nazi Death Camp, 11-12.

73 The only exception is a commemorative plaque, most probably stemming from the 1980s and providing false information about the number 
and provenance of the victims (including 1,500 Poles), displayed in one of the rooms in the museum building.

74 It is, obviously, not to deny the involvement of the representatives of Jewish organisations - the US Holocaust Memorial Museum, American Jewish Committee or the Rabbinical Commission in Poland - in the process of redesigning the memorial site at Bełżec at all its stages. Rather, taking as a vantage point the experience of the visitor who enters the memorial landscape (without much knowledge about the complex decision-making processes and actors involved in its inception), one is struck by the persistence with which the memorial reproduces the somewhat essentialistically framed 'otherness' of the victims of the camp.

75 Krmpotich et al., 'The substance of bones'.

76 T. Ingold, 'Materials against materiality', Archaeological Dialogues, 14:1 (2007), 11.

77 Fontein and Harries, 'The vitality and efficacy', 120.

78 S. Sheikh, 'Forensic theater: Grupa Spomenik's Pythagorean lecture: mathems of re-association', in Forensic Architecture (ed.), Forensis: The Architecture of the Public Truth (Berlin: Sternberg Press, 2014), p. 179.

79 Taking place after the mass graves at the site were permanently sealed off, the inhumation of the Bełżec tooth established, therefore, a fascinating precedent: buried outside, or on the margins, of the direct area of the initially protected graves, into which it could not be incorporated, the material presence of the tooth again exposed the fragility and impermanence of the boundaries set to separate the living from the dead.

80 Fontein, 'Remaking the dead'.

81 Information provided by Ewa Koper, Museum-Memorial Site at Bełżec. Interviews conducted by the author on 16 October 2013 and 24 September 2014.

82 Relation 34, anonymised, MMPB.

83 His letter given to the museum employees (now, together with the ring, stored in the magazine of the State Museum at Majdanek) is quoted in Gross and Grudzińska Gross, Golden Harvest, pp. 123-4.

84 Quoted in Eliza Leszczyńska-Pieniak, 'Ciężar zmiętej kartki', Zamojski Kwartalnik Kulturalny, 3 (2011), 72.

85 K. Cichoń and E. Janicka, 'Portrety powietrza', Atlas Sztuki, 21 (2006).

86 Relation 65, anonymised, MMPB.

\section{Bibliography}

\section{Archives}

Archive of the Council for the Protection of Memory of Combat and Martyrdom (ROPWiM), Warsaw, Poland

Archive of the Institute of National Memory (IPN), Warsaw, Poland 
Archive Majdanek State Museum (MMP), Lublin, Poland

Archive Museum-Memorial Site Bełżec (MMPB), Bełżec, Poland

\section{Books and journals}

Aleksiun, N., 'Christian corpses for Christians! Dissecting the anti-semitism behind the cadaver affair of the second Polish Republic', East European Politics and Societies, 25:3 (2011), 393-409

Betzec: Nazi Death Camp (Vienna: Grasl, 2006)

Berger, S., Experten der Vernichtung: Das T4-Reinhardt-Netzwerk in den Lagern Belzec, Sobibor und Treblinka (Hamburg: Hamburger Edition, 2013)

Bisky, J., 'Die Beerdigung eines Zahns', Süddeutsche Zeitung, 13 May 2005. URL: www.sueddeutsche.de/kultur/holocaust-mahmnal-in-berlin-diebeerdigung-eines-zahns-1.415866 (accessed 5 December 2013)

Butler, J., Precarious Life: The Powers of Mourning and Violence (New York and London: Verso, 2006)

Cichoń, K. and E. Janicka, 'Portrety powietrza', Atlas Sztuki, 21 (2006), unnumbered pages.

Connolly, K., 'Jews angry over memorial plan for death camp tooth', Telegraph, 13 May 2005. URL: www.telegraph.co.uk/news/worldnews/ europe/germany/1489942/Jews-angry-over-memorial-plan-for-deathcamp-tooth.html (accessed 5 December 2013)

Deutsche Presse-Agentur, 'Lea Rosh gibt Backenzahn an Belzec züruck', Spiegel Online, 13 May 2005. URL: www.spiegel.de/politik/deutschland/ mahnmal-streit-lea-rosh-gibt-backenzahn-an-belzec-zurueck-a356057.html (5 December 2013)

Elsner, A., 'Memorializing those murdered at Belzec', 1995. URL: http:// remember.org/educate/belzec.html (accessed 6 December 2013)

Fontein, J., 'Remaking the dead, uncertainty and the torque of human materials in Northern Zimbabwe', in F. Stepputat (ed.), Governing the Dead: Sovereignty and the Politics ofDead Bodies (Manchester: Manchester University Press, 2014), 114-40

Fontein, J. and J. Harries, 'The vitality and efficacy of human substances', Critical African Studies, 5 (2013), 115-26

Grabowski, J. and D. Libionka (eds), 'Wstęp', in Klucze i kasa: O mieniu żydowskim $w$ Polsce pod okupacja niemiecka $i$ we wczesnych latach powojennych 1939-1950 (Warsaw: Stowarzyszenie Centrum Badań nad Zagładą Żydów, 2014), pp. 7-28

Gross, J. T. and I. Grudzińska Gross, Golden Harvest: Events at the Periphery of the Holocaust (New York and Oxford University Press, 2012)

Hallam, E., 'Articulating bones: an epilogue', Journal of Material Culture, 15 (2010), 465-92

Harrison, S., Dark Trophies: Haunting and the Enemy Body in Modern War (New York and London: Berghahn, 2014)

Ingold, T., 'Materials against materiality', Archaeological Dialogues, 14:1 (2007), 1-16

Kola, A., Betzec: The Nazi Camp for Jews in the Light of Archeological Sources (Warsaw and Washington: ROPWiM, 2000) 
Krmpotich, C., J. Fontein and J. Harries, 'The substance of bones: the emotive materiality and affective presence of human remains', Journal of Material Culture, 15 (2010), 371-84

Kuwałek, R., Obóz zagłady w Bełzcu (Lublin: Państwowe Muzeum na Majdanku, 2010)

Kuwałek, R., 'Obozy koncentracyjne i ośrodki zagłady jako miejsca pamięci', in F. Tych and M. Adamczyk-Grabowska (eds), Następstwa zagłady Żydów: Polska 1944-2010 (Lublin: Wydawnictwo Uniwersytetu Marii Curie-Skłodowskiej, Żydowski Instytut Historyczny, 2012), pp. 493-525

Lamm, M., The Jewish Way in Death and Mourning (New York: Jonathan David Publishers, 2000)

Leder, A., Prześniona rewolucja: Ćwiczenia z logiki historycznej (Warsaw: Wydawnictwo Krytyki Politycznej, 2014)

Leszczyńska-Pieniak, E., 'Ciężar zmiętej kartki', Zamojski Kwartalnik Kulturalny, 3 (2011), 69-72

Levi-Strauss, C., Tristes Tropiques (London: Penguin Classics, 2012)

Libionka, D. (ed.), Obóz zagłady w Bełżcu w relacjach ocalonych i zeznaniach polskich świadków (Lublin: Państwowe Muzeum na Majdanku, 2013)

Lis, D. (ed.), Wokół 'Złotych żniw': Debata o ksiązce Jana Tomasza Grossa i Ireny Grudzińskiej-Gross (Kraków: Znak, 2011)

Muralczyk, W., 'Bełżec: kopalnia złota - Raport z pustego pola', Świat, 17 (1956), reprinted in D. Lis (ed.), Wokół 'Złotych żniw': Debata o książe Jana Tomasza Grossa i Ireny Grudzińskiej-Gross (Kraków: Znak, 2011), pp. $49-55$

Posel, D. and P. Gupta, 'The life of the corpse: framing reflections and questions', African Studies, 68 (2009), 299-309

Reszka, P. and S. Szewc, 'Liczy się szacunek', Gazeta Wyborcza Lublin, 16 May 2005

Rusiniak, M., Obóz zagłady Treblinka II w pamięci społecznej (1943-1989) (Warsaw: Neriton, 2008)

Schudrich, M., 'Let Belzec victims finally rest in peace', 25 July 2003. URL: http://forward.com/opinion/7765/let-belzec-victims-finally-restin-peace (accessed 3 October 2015)

Schulze, C., 'Lea Rosh brüskiert Jüdische Gemeinde', Spiegel Online, 11 May 2005. URL: www.spiegel.de/kultur/gesellschaft/holocaust-mahnmallea-rosh-brueskiert-juedische-gemeinde-a-355600.html (accessed 5 December 2013)

Sheikh, S., 'Forensic theater: Grupa Spomenik's Pythagorean lecture mathems of re-association', in Forensic Architecture (ed.), Forensis: The Architecture of the Public Truth (Berlin: Sternberg Press, 2014), 166-88

Stepputat, F., 'Introduction', in F. Stepputat (ed.), Governing the Dead: Sovereignty and the Politics of Dead Bodies (Manchester: Manchester University Press, 2014), pp. 3-10

Strzelecki, A., 'The plunder of victims and their corpses', in Y. Gutman and M. Berenbaum (eds), Anatomy of the Auschwitz Death Camp (Bloomington, IN: Indiana University Press, 1998)

Sturdy Colls, C., Holocaust Archaeologies: Approaches and Future Directions (New York: Springer, 2015) 
Verdery, K., The Political Life of Dead Bodies: Reburial and Postsocialist Change (New York: Columbia University Press, 1999)

Weiss, A., 'Let the victims of Bełżec rest in peace', Jerusalem Post, 14 August 2002

Williams, H., 'Death warmed up: the agency of bodies and bones in early Anglo Saxon cremation rites', Journal of Material Culture, 9 (2004), 263-91

Wóycicka, Z., Arrested Mourning: Memory of the Nazi Death in Poland, 1944-1950 (Frankfurt am Main: Peter Lang, 2013)

Young, J., At Memory's Edge: After Images of the Holocaust in Contemporary Art and Architecture (New Haven, CT and London: Yale University Press, 2000)

Zaremba, M., Wielka Trwoga. Polska 1944-1947: Ludowa Reakcja na kryzys (Kraków: Znak, 2012)

Zawodna, M., 'O porządkowaniu poobozowego świata: Sposby postępowania ze szczatkami ludzkimi na terenach byłego KL AuschwitzBirkenau od momentu ostatecznej likwidacji obozu do powstania muzeum', Zagłada Żydow: Studia i materiały, 8 (2012), 145-75

ZB, 'Der Lea Rosh-Skandal', Berliner Kurier, 13 May 2005. URL: www. berliner-kurier.de/archiv/es-war-eine--grausamkeit--den-backenzahnmitzunehmen--die-vize-direktorin-der-gedenkstaette-in-auschwitz-istueber-den-vorfall-schockiert-der-lea-rosh-skandal,8259702,4098206. html (accessed 5 December 2013) 